\title{
Morpho-functional studies regarding the pathogenesis of the equine endometrosis with special emphasis on uterine secretions - preliminary results
}

\author{
Christine Hoffmann', Fuller W. Bazer², Jörg Klug ${ }^{3}$, W. R. (Twink) Allen', Heike Aupperle', Christin Ellenberger ${ }^{7}$ \\ und Heinz-Adolf Schoon?
}

Institut für Veterinär-Pathologie der Universität Leipzig', Dept. for Animal Science Texas A\&M University, Texas², Institut für Molekularbiologie und Tumorforschung (IMT), Philipps-Universität Marburg ${ }^{3}$ and University of Cambridge, Dept. of Clinical Vet. Medicine, Equine Fertility Unit, Newmarket ${ }^{4}$

\begin{abstract}
Summary
The aim of the study was to investigate potential etiologic factors (e.g. endometritis) for the equine endometrosis as well as to determine possible effects by seasonal, cyclical and pregnancy-associated influences. Additionally, immunohistochemical methods were established to characterize the glandular secretion pattern of mares suffering from endometrosis compared to healthy control mares. For the histomorphological and immunohistochemical examinations 952 endometrial biopsies from 620 mares were used. The endometrosis can be divided in a destructive and a non destructive form, which can be either active or inactive. However, concerning quality and quantity there were no seasonal, cyclical or pregnancy-associated influences detectable. While the uterine secretion pattern of uteroglobin, calbindin, uteroferrin, uterocalin and glycogen follows a typical cycle-dependent staining intensity in the intact endometrium, the glandular epithelia within the fibrotic foci failed to. The latter revealed a distinct variety concerning the distribution and the staining intensity. These results indicate that subsequent disturbances of the uterine micro-environment are important factors leading to reduced fertility in mares suffering from endometrosis.
\end{abstract}

Keywords: mare, endometrosis, endometrial biopsy, uterine secretion pattern

\begin{abstract}
Morphofunktionale Untersuchungen zur Pathogenese der Endometrose des Pferdes unter besonderer Betrachtung des uterinen Sekretionsmusters - vorläufige Ergebnisse

Ziel der Untersuchung war die Ermittlung potentieller ätiologischer Faktoren (z. B. Endometritis) für die equine Endometrose sowie die Bestimmung eines möglichen Einflusses saisonaler, zyklischer und trächtigkeitsassoziierter Variationen. Darüber hinaus sollte, im Vergleich zu gesunden Kontrollstuten, eine immunhistologische Charakterisierung der glandulären Sekretionsprodukte bei Endometrosepatientinnen erfolgen. Als Material für Histologie und Immunhistologie standen 952 Endometriumbiopsien von 620 Stuten zur Verfügung. Die Endometrose tritt in destruierender und nicht destruierender Form, aktiv oder ruhend auf. Nachweisbar sind weder saisonale, zyklische noch trächtigkeitsassoziierte Einflüsse. Dies betrifft sowohl qualitative als auch quantitative Gesichtspunkte. Während das uterine Sekretionsmuster von Uteroglobin, Calbindin, Uteroferrin, Uterocalin und Glycogen im intakten zyklischen Endometrium einem typischen, zyklusabhängigen Verlauf folgt, ist dies in den glandulären Epithelien fibrotischer Herde nicht nachweisbar. Stattdessen zeichnen sich diese Areale durch eine große Variabilität hinsichtlich Verteilung und Reaktionsintensität aus. Diese Resultate werden von den Autoren als Hinweis für eine fertilitätsmindernde Beeinflussung des uterinen Mikromilieus im Rahmen der Endometrose interpretiert.
\end{abstract}

Schlüsselwörter: Reproduktion, Stute, Endometrose, Endometriumbiopsie, uterines Sekretionsmuster

\section{Introduction}

The term endometrosis describes a periglandular and/or stromal endometrial fibrosis including glandular alterations in fibrotic foci. Single glands and/or glandular nests can be affected (Schoon et al. 1995). The degree of endometrosis increases with the age of the mare; however, there is no correlation to the number of foalings (Schoon et al. 1997). Until now the etiology as well as the pathogenesis of this important cause for equine infertility remains unknown.

The beginning fibrosis is characterized by large polygonal stromal cells of type I synthesizing collagen fibres. In advanced fibrosis, metabolic active or inactive stromal cells of type II without signs of collagen synthesis as well as myofibroblasts are the predominant cells (Raila 2000).
In the initial stages of endometrosis, the epithelia of the fibrotic glands are characterized by a cycle asynchronous differentiation compared to non affected glands (Raila 2000). Subsequently an epithelial degeneration and a glandular dilatation can develop (Schoon et al. 1992). As a result, marked differences occur in the fibrotic foci concerning the histochemical patterns (Schoon et al. 1995) as well as the expression of the steroid hormone receptors, the proliferation intensity (Aupperle et al. 1999) and the intermediate filaments (Aupperle 1997). These dysfunctions of the fibrotic glands may lead to qualitative and quantitative alterations of the endometrial secretions and consequently to a disturbance of the intrauterine micro-environment (Hein 2000).

However, in animal species, like mares, in which the trophoblast is non-invasive the uterine secretions seem consi- 
derably more likely to play an important role in the maintenance of the conceptus (Amoroso 1951). Throughout the estrous cycle of the mare numerous secretory proteins and carbohydrates are present (McDowell et al. 1987, Freeman et al. 1990), with a higher accumulation of endometrial proteins in the luteal-phase compared to other mammalian species examined until now (Beier-Hellweg et al. 1995). The functions of the molecules identified are different. While glycogen (Freeman et al. 1990), the calcium-binding-protein calbindin (Nikitenko et al. 1998), the iron-binding protein uteroferrin (Roberts et al., 1986) and the lipocalin uterocalin (Crosset et al. 1998) probably supply the conceptus, the role of uteroglobin in the reproductive tract is unknown. In other tissues multiple functions of uteroglobin like anti inflammatory and anti chemotactic activities are discussed (Mukherjee et al. 1999).

The aim of this study was the histomorphological and immunohistochemical characterization of endometrosis in order to find out which factors possibly influence the progress of this disease. Uterine secretion patterns were examined in endometrial biopsies collected in mares during the estrous cycle as well as in mares showing degenerative lesions varying in quality and quantity, using histochemical and immunohistochemical techniques.

\section{Materials and methods}

952 endometrial biopsies from 620 mares were studied. All specimens showed signs of endometrosis varying in quality and quantity (active/inactive, mild to severe). The animals examined and the respective targets of the analyses are summarized in Table 1 .

The biopsies were fixed in formalin, embedded in paraffin and stained with Hematoxylin-Eosin (H.-E.).

Glycogen was detected by the PAS-reaction with and without a-Amylase digestion. Alcian blue staining before and after a prior treatment with Testes- and Streptomyces-hyaluronidase was used to identify the extracellular matrix in the periglandular fibrosis.

The expression of steroid hormone receptors, Ki-67-antigen, laminin, vimentin, desmin, smooth-muscle-a-actin (Aupperle et al. 1999, Raila 2000), as well as the endometrial proteins uteroglobin, calbindin, uteroferrin and uterocalin (Hoffmann, unpublished data) were detected in biopsies selected representatively by immunohistochemistry using the PAP-technique. The Immuno Reactive Score, established by Özgen et al. (1997) to evaluate the steroid hormone receptor expression, was modified into a Secretion-Score (SSc) to precisely assess the immunohistochemical reactions.

\section{Results}

Histomorphological classification of the endometrosis

Using H.E.-stained slides it was possible to distinguish between a destructive and a non destructive appearance of endometrosis. While a non destructive endometrosis is character- ized by mild alterations of the glandular epithelia, the glands in destructive endometrosis, occurring in $25 \%$ of the cases examined, showed signs of an extensive epithelial degeneration with a loss of the typical glandular architecture. Subtypes

Tab 1 Mares investigated and the respective target of analysis. Übersicht über das Tiergut und die damit verfolgten Untersuchungsziele

\begin{tabular}{|c|l|l|}
\hline $\begin{array}{c}\text { Number } \\
\text { of mares }\end{array}$ & \multicolumn{1}{|c|}{ Target of analysis } & \multicolumn{1}{|c|}{ Characteristic of the uterine biopsies } \\
\hline 508 & $\begin{array}{l}\text { Characterization of different } \\
\text { types of endometrosis and } \\
\text { possible seasonal influences }\end{array}$ & $\begin{array}{l}\text { Routine biopsies during the } \\
\text { * } \text { breeding season (May to July, } \mathrm{n}=242 \text { ) } \\
\text { * } \text { non-breeding season (Nov. to Feb., } \mathrm{n}=266 \text { ) }\end{array}$ \\
\hline 79 & $\begin{array}{l}\text { Progress of endometrosis } \\
\text { over a longer period of time }\end{array}$ & $\begin{array}{l}\text { Repeated biopsies of the same mare } \\
\text { * over a period from 6 months to 5 years }\end{array}$ \\
\hline 7 & $\begin{array}{l}\text { Cyclic variabilities of } \\
\text { endometrosis and } \\
\text { characterization of the uterine } \\
\text { secretion pattern during the } \\
\text { estrous cycle }\end{array}$ & $\begin{array}{l}\text { Repeated collection during the estrous cycle } \\
\text { * days 0 (ovulation), 5,10,13,16,19, 21 } \\
\text { * determination of estradiol- and } \\
\text { progesterone plasma concentrations }\end{array}$ \\
\hline 8 & $\begin{array}{l}\text { Influence of pregnancy on the } \\
\text { development of endometrosis }\end{array}$ & $\begin{array}{l}\text { Biopsies prior to mating and after following } \\
\text { pregnancy } \\
\text { * days 3, 7, 10 or 28 post partum }\end{array}$ \\
\hline 20 & $\begin{array}{l}\text { Influence of endometritis on } \\
\text { the progress of endometrosis }\end{array}$ & $\begin{array}{l}\text { Experimentally induced bacterial } \\
\text { endometritis and subsequent treatments } \\
\text { * 10 paired biopsies from 20 mares } \\
\text { * over a period of 2 years }\end{array}$ \\
\hline & & \\
\hline
\end{tabular}

of metabolic active (ovoid, hypochromatous nuclei) and inactive (spindle-shaped, hyperchromatous nuclei) stromal cells formed the periglandular fibrosis. The coincidence of both types in one biopsy is frequent.

Immunohistochemical and histochemical examination of the different types of endometrosis

Obvious differences occurred in the stromal cells of periglandular fibrosis as well as in the glandular epithelia depending on type, activity and degree of endometrosis. The results of the immunohistochemical and the histochemical analysis are summarized in Table 2 .

Statistical analysis of the factors possibly influencing the progress of the endometrosis

A statistically significant coincidence of endometrosis and endometritis is obvious in cases of destructive endometrosis, independent of the degree of the periglandular fibrosis $(p=0.05)$ and in cases of severe non destructive endometrosis $(p<0.005)$. Additionally, 10 of 20 mares with an experimentally induced endometritis and subsequent treatments showed a temporary metabolic activation of fibrotic stromal cells five days post infection. However, the degree of endometrosis neither increased nor decreased over the 2-yearperiod of the experiment. On the other hand seasonal and cyclic changes as well as pregnancies did not influence the type and/or progress of the endometrosis.

Immunohistochemical and histochemical examination of uterine secretion during the estrous cycle

Histochemical and immunohistochemical reaction products of the uterine secretions were detectable in the cytoplasm of the glandular epithelia, within the lumina of the glands and 
sporadically in the cytoplasm of the luminal epithelia. Maximal SSc-values of the uterine secretions examined were observed in the mid and/or basal endometrial glands.

Tab 2 Immunohistochemical and histochemical examination of periglandular fibrosis, basal lamina and glandular epithelia within fibrotic areas

Immunhistologische und histochemische Befunde der periglandulären Fibrose, der Basallamina und der glandulären Epithelien innerhalb fibrotischer Herde

\begin{tabular}{|c|c|c|c|c|c|}
\hline \multirow[b]{2}{*}{\begin{tabular}{|c|}
$\begin{array}{c}\text { Tissue structure } \\
\text { examined }\end{array}$ \\
\end{tabular}} & \multirow[b]{2}{*}{ Parameter } & \multicolumn{2}{|c|}{$\begin{array}{l}\text { Non destructive } \\
\text { endometrosis }\end{array}$} & \multicolumn{2}{|c|}{$\begin{array}{c}\text { Destructive } \\
\text { endometrosis }\end{array}$} \\
\hline & & $\begin{array}{l}\text { active } \\
\text { fibrosis }\end{array}$ & $\begin{array}{l}\text { inactive } \\
\text { fibrosis } \\
\end{array}$ & $\begin{array}{c}\text { active } \\
\text { fibrosis }\end{array}$ & $\begin{array}{l}\text { inactive } \\
\text { fibrosis }\end{array}$ \\
\hline \multirow{4}{*}{$\begin{array}{l}\text { Periglandular } \\
\text { fibrosis }\end{array}$} & $\begin{array}{c}\text { steroid hormone } \\
\text { receptors }{ }^{1}\end{array}$ & $\sqrt{3}$ & $\sqrt{3}$ & $\sqrt{2}$ & $\sqrt{2}$ \\
\hline & $\begin{array}{c}\text { Ki-67-antigen } \\
\text { (proliferation activity) }\end{array}$ & $(+)$ & -- & $(+)$ & -- \\
\hline & $\begin{array}{c}\text { smooth-muscle- } \\
\alpha \text {-actin }\end{array}$ & $+(+)$ & $+(+)$ & $++(+)^{2}$ & $+(+)$ \\
\hline & $\begin{array}{c}\text { acid } \\
\text { mucopolysaccharides } \\
\end{array}$ & ++ & + & +++ & + \\
\hline Basal lamina & $\operatorname{laminin}^{5}$ & $+(+)^{4}$ & $++^{4}$ & +++ & +++ \\
\hline \multirow{2}{*}{$\begin{array}{l}\text { Glandular } \\
\text { epithelia }\end{array}$} & $\begin{array}{l}\text { steroid hormone } \\
\text { receptors }^{1}\end{array}$ & $\hat{\imath}$ & $\sqrt{3}$ & तn $\Omega^{3}$ & $\sqrt{ }(\sqrt{ })^{3}$ \\
\hline & vimentin & $+^{4}$ & + & $++(+)$ & ++ \\
\hline \multicolumn{2}{|c|}{$\begin{array}{l}1 \text { compared with the expression of } \\
\text { steroid hormone receptors in unaffected glands } \\
2 p<0.005 \\
3 p<0.001 \\
4 \text { depending on the degree of endometrosis } \\
5 \text { degree of discontinuity }\end{array}$} & 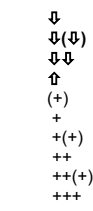 & \multicolumn{3}{|c|}{$\begin{array}{l}=\text { mild decrease } \\
=\text { mild to moderate decrease } \\
=\text { moderate decrease } \\
=\text { mild increase } \\
=\text { slight } \\
=\text { mild } \\
=\text { mild to moderate } \\
=\text { moderate } \\
=\text { moderate to severe } \\
=\text { severe }\end{array}$} \\
\hline
\end{tabular}

The staining intensity, the percentage and localization of positive cells revealed typical reaction patterns during the estrous cycle. However, the day of the cycle on which a maximum was detected varied between the mares. An overview of the proteins and glycogen reaction patterns during the estrous cycle is presented in Table 3 .

Immunohistochemical and histochemical examination of glandular secretion patterns in endometrosis

In comparison to non affected glands, most of the epithelia in periglandular fibrosis showed a decreased staining intensity of the uterine secretion products examined, except for uteroferrin.

In contrast, uteroferrin presented a variable reaction pattern; the highest staining-intensities were achieved in the glandular epithelia within areas of a severe non destructive as well as destructive endometrosis. A schematic overview is presented in Table 4. The influence of the fibrosis activity on the expression of the uterine secretion products examined was undetectable.

Tab 3 Glandular secretion patterns of the proteins and glycogen examined throughout the estrous cycle Expression der sekretorischen Proteine und Nachweis des Glykogens innerhalb endometrialer Drüsen im Verlaufe des Zyklus

\begin{tabular}{|c|c|c|c|}
\hline $\begin{array}{c}\text { Uterine secretion } \\
\text { product }\end{array}$ & $\begin{array}{c}\text { Day(s) of } \\
\text { maximal SSc }\end{array}$ & $\begin{array}{c}\text { Predominant } \\
\text { glandular } \\
\text { localization }\end{array}$ & $\begin{array}{c}\text { Basic staining-intensity } \\
\text { throughout the whole } \\
\text { estrous cycle }\end{array}$ \\
\hline Uteroglobin & 21,0 and 13 & mid and basal glands & low values \\
\hline Glycogen & $5-10,19$ & mid glands & low values \\
\hline Calbindin & $5-10,21$ & apical, mid and basal & glands \\
\hline Uterocalin & $10-13$ & mid and basal glands & none or low values \\
\hline Uteroferrin & 13 & apical, mid and basal \\
glands & None or low values \\
\hline
\end{tabular}

\section{Conclusions}

By the histomorphological and immunohistochemical techniques applied, a distinct differentiation of the endometrosis in destructive and non destructive types was possible.

The high glandular expressions of vimentin as well as the severely damaged basal lamina are features of the advanced

Tab 4 Glandular secretion patterns of the proteins and glycogen examined within the endometrotic foci

Sekretionsmuster der Proteine bzw. des Glykogens in glandulären Epithelien endometrotischer Areale

\begin{tabular}{|c|c|c|c|c|c|}
\cline { 2 - 6 } \multicolumn{1}{c|}{} & Uteroglobin & Calbindin & Uteroferrin & Uterocalin & Glycogen \\
\hline $\begin{array}{c}\text { Glandular epithelia in } \\
\text { fibrotic foci }\end{array}$ & $\Downarrow / \uparrow$ & $\Downarrow / \uparrow$ & $\Downarrow / \uparrow$ & $\S / \uparrow$ & $\S / \uparrow$ \\
\hline
\end{tabular}

${ }^{1}$ compared with unaffected glandular epithelia

$\checkmark$ decreased SSc

$\hat{\imath}$ increased SSc

$\uparrow$ increased SSc, nearly exclusively seen in non destructive endometrosis

epithelial degeneration in destructive fibrosis. This progredient character is likely attributed to the increased number of contractile myofibroblasts compared to that of non destructive fibrosis.

Neither a pregnancy nor seasonal and/or cyclical endocrine variations seem to have a remarkable influence on the progress of endometrosis. The hypothesis that fibrotic glands became independent of the uterine control mechanisms (Schoon et al. 1995) is confirmed.

Moreover, the high expression of steroid hormone receptors observed only in active non destructive endometrosis refers to a reciprocal correlation between the epithelia and the fibrotic stromal cells. As discussed in previous studies (Raila 2000), different growth factors as possible mediators and other cytokines may also be involved.

The proteins investigated as well as glycogen showed typical expression patterns throughout the estrous cycle; however, distinct individual differences between the mares examined were obvious.

Deficient protein secretion patterns in uterine and cervical secretions of mares suffering from moderate or severe endometrosis has been demonstrated by Hein (2000) by means of electrophoresis. It has to be considered that numerous of these proteins are not yet identified. Even glycogen and the four proteins investigated in this study showed deviations of the epithelial secretion patterns within the fibrotic areas compared to the unaffected glands. This phenomenon is probably at least one factor leading to a disturbance of the intrauterine micro-environment, relevant in the pathogenesis of endometrosis induced fertility problems in the mare.

\section{Literature}

Amoroso E. C. (1951): Placentation. in Marshall's Physiology of reproduction, $3^{\text {rd }}$ edn., Vol. II, Ed. A. S. Parkes, Longman Green, London, 127-311

Aupperle H. (1997): Immunhistologische Untersuchungen am Endometrium der Stute. Leipzig, Univ., Veterinärmed. Fakultät, Diss. 
Aupperle H., S. Özgen, H.-A. Schoon, D. Schoon, H. O. Hoppen, H. Sieme and A. Tannapfel (1999): Cyclical endometrial steroid hormone receptor expression and proliferation intensity in the mare. Equine Vet. J. 32, 228-232

Beier-Hellweg K., H. Kremer, B. Bonn, D. Linder, H. Bader and H. M. Beier (1995): Partial sequencing and identification of three proteins from equine uterine secretion regulated by progesterone. Reprod. Dom. Anim. 30, 295-298

Crossett B., S. Suire, A. Herrler, W. R. Allen and F. Stewart (1998): Transfer of a uterine lipocalin from the endometrium of the mare to the developing equine conceptus. Biol. Reprod. 59, 483-490

Freeman K. P., J. F. Roszel, S. H. Slusher and M. Castro (1990): Variation in glycogen and mucins in the equine uterus related to physiologic and pathologic condition. Theriogenology 33, 799 808

Hein K. (2000): Morpho-funktionelle Untersuchungen an der Cervix uteri und am Endometrium der Stute im Verlauf des Zyklus. Hannover, Univ., Veterinärmed. Fakultät, Diss.

McDowell K. J., D. C. Sharp and W. Grubaugh (1987): Comparison of progesterone and progesterone and estrogen on total and specific uterine proteins in pony mares. J. Reprod. Fert. Suppl. 35, 335-342

Mukheriee A. B., G. C. Kundu and G. Mantile-Selvaggi (1999): Uteroglobin: a novel cytokine? Cell. Mol. Life Sci. 55, 771-787

Nikitenko L., G. Morgan, S. I. Kolesnikov and F. B. P. Wooding (1998): Immunocytochmeical and in situ hybridization studies of the distribution of Calbindin D9K in the bovine placenta throughout pregnancy. J. Histochem. Cytochem. 46, 679-688
Özgen S., K. Rasch, G. Kropp, H.-A. Schoon, H. Aupperle, H. Sieme and E. Klug (1997): Aetiopathogenesis and therapy of equine hydromucometra: preliminary data. Pferdeheilkunde 13, 533-534

Raila G. (2000): Zur Pathogenese der Endometrose der Stute - Morphologisch-funktionelle Untersuchungen-. Leipzig, Univ., Veterinärmed. Fakultät, Diss.

Roberts R. M., T. J. Raub and F. W. Bazer (1986): Role of uteroferrin in transplacental iron transport in the pig. Fedn. Proc. Fedn. Am. Socs. Exp. Biol. 45, 2513-2518

Schoon H.-A., D. Schoon and E. Klug (1992): Uterusbiopsien als Hilfsmittel für Diagnose und Prognose der Fertilitätsstörungen der Stute. Pferdeheilkunde 8, 355-362

Schoon H.-A., D. Schoon, B. Kötter, A. Runge and E. Klug (1995): Zur Pathogenese und Prognose der Endometrose der Stute. in Dtsch. Vet. Med. Ges. (Hrsg.): Bericht des 21. Kongresses der DVG, Bad Nauheim, 273-282

Schoon H.-A., D. Schoon and E. Klug (1997): Die Endometriumbiopsie bei der Stute im klinisch-gynäkologischen Kontext. Pferdeheilkunde 13,453-464

Christine Hoffmann

Institut für Veterinär-Pathologie

Universität Leipzig

An den Tierkliniken 33

04103 Leipzig

chhoff@rz.uni-leipzig.de 